\title{
Corporate Structural Changes And Financial Reporting In Nigerian Banking Industry
}

\author{
Festus Olaoye \\ Department of Accounting, Faculty of Management Sciences, \\ Ekiti State University, Ado-Ekiti, Ekiti State \\ Oyindamola Adesola Fakiyesi \\ Department of Accounting, Faculty of Management Sciences, \\ Ekiti State University, Ado-Ekiti, Ekiti State
}

\begin{abstract}
This study examined the impact connection between corporate structural changes and financial reporting in Nigerian Banking Industry. The study specifically analyzed the impact of changes in share capital and change in share premium on profit after tax, and earning per share. The study focused on five commercial banks in Nigerian including Access banks Plc, Diamond banks Plc, First bank Plc, Guaranty trust bank Plc, and First City Monument banks Plc. Secondary data were collected from annual reports of sampled banks over a period of five years (2011-2015) and were analyzed using panel data estimators such as pooled OLS estimator, fixed effect estimator, and random effect estimator. The most consistent and efficient estimator revealed that corporate structural changes measured in terms of changes in share capital has insignificant positive impact of profit after tax given the reported coefficient estimate corresponding to change in share capital that stood at 5.729072 alongside probability value of 0.308 . Corporate structural changes measured in terms changes in share premium exert insignificant negative impact on profit after tax given the reported coefficient estimate of -.5492376 alongside probability values of 0.122 . Result also showed that corporate structural changes measured in terms of change in share capital exert significant negative impact on earnings per share, while corporate structural changes measured in terms of change in share premium exert insignificant impact on earnings per share. The study established that any changes in the structural composition of finance mix in terms share capital and share premium exert measurable influence of indicators such as profit after tax and earnings per share reported by firms for awareness of the operational outcome for the years to stakeholders including government, regulatory authorities as well as standpoint for investment by prospective investors. Thus firms in the banking industry should objectively design corporate structural framework that can withstand flexibility and dynamics of business operation in the industry, so as to guide against excessive inconsistencies in financial reporting as a result of structural changes.
\end{abstract}

Keywords: Corporate Structural Changes, Financial Reporting, Nexus

\section{INTRODUCTION}

Corporate structure has continued to define the pattern and position of firms performance all over the world, with growing consensus pointing to the influence of changing corporate structure (both in terms of ownership and capital structure) on corporate performance (Peterson, kitakogelu \& Olayinka 2017). According to Chechet \& Olayiwola (2014) business entity must take close cognizance of its structure especially in term of capital to maintain balance in the dynamics of business environment, thus pointing to the importance of structure in the discourse of operational performance financial reporting. Structure of a firm in terms of capital (i.e capital structure) embodies the way the firm finances its operation via the 
combination of debt and equity (Aftab, Eshan, Naseer \& Awan 2012; Dare and Sola, 2010). This form of corporate structure is very critical and fundamental in the life of a business not only for profit maximization purpose, but also for sustainability and optimal attainment of the overall business objectives. There is a rising number of empirical investigation on structural related discourse ranging from issues relating to capital structure as well as ownership structure especially in the context of corporate performance (see Siddiqui \& Shoaib, 2011; Oke \& Afolabi, 2011; San and Heng, 2011; Muritala 2012; Aftab, Eshan, Naseer \& Awan 2012; Abbadi \& Aburub, 2012; Velnampy \& Niresh, 2012; Khalat 2013; Lawal, 2014; Chechet \& Olayiwola, 2014; Muritala, 2012; Chandrasekharan 2012; Osuji \& Odita, 2012; Ogede, Ogede, \& Alewi, 2013). In Nigeria several empirical investigations had been conducted to track the influence of structural changes in terms of capital structure, on firms performance in Nigeria, for example Uremadu \& Efobi (2012) analyze the impact of capital structure on firm's performance evidence from the manufacturing firms of Nigeria, relating capital structure measured in terms of long-term debt, ratio of long-term debt to total liability, and ratio of short-term debt to total liability, and equity capital to total liability. Investigation conducted by Oke \& Afolabi (2011) related capital structure (measured in terms of debt financing, equity financing, and debtequity ratio) to performance of firms, Chechet \& Olayiwola (2014) measured capital structure in term of debt ratio and equity ratio, Julius, Nwidobie \& Adesina (2015) measured capital structure in term of equity and debt. Using identical measure of capital structure other studies including Lawal (2014), Muritala (2012), Ayanda, Christopher, Mudashiru \& Issac (2013), and Chandrasekharan (2012) also analyze capital structure of firms in Nigeria, However all these studies does not relate changes in the components of capital structure within the fiscal years with performance indicators which forms the basis for financial reporting. The kernel of this study therefore is to take cognizance of the structural changes to equity components like share capital, share premium within the fiscal year, and track the influence of such changes on indicators of financial performance reported in the annual statement of account that defines the financial reporting of an organization. Specifically the study set out to:

- Examine the effect of changes in share capital on reported performance indicators

- Analyze the influence of changes in share premium on reported performance indicators

\section{Corporate Structure}

\section{LITERATURE REVIEW}

Corporate structure connotes the framework of finance and/or ownership of a firm, as defined by the source of finance used for its operation. In financial term, corporate structure means the way a firm finances their assets through the combination of equity, debt, or hybrid securities (Saad, 2010). In short, capital structure is a mixture of a company's debts (long-term and shortterm), common equity and preferred equity. Capital structure of a firm involves two key components- debt and equity. The optimal capital structure of the firm is one that minimizes the cost of capital, in other words, an optimal balance between the proportion of debt and the proportion of equity would result in the overall minimization of the cost associated with these components. Furthermore, it is essential that these costs are weighted across the various sources of funds to ensure that the overall cost is the minimum. Based on the basic concepts of the capital structure, firms' managers make decisions on what type of funds and at what levels in terms of magnitude, will lead to the overall minimization of the costs associated with procuring these funds. Therefore, the demand and supply of funds affect the corporate structure, but at the same time, the riskiness associated with the firm's cash flows affects the corporate structure. In other words, the more the volatility of the cash flows of the firm, the more will be the impact of this risk on the firm's ability to raise debt and/or equity. Therefore, it can be stated that the capital structure decisions are based on the impact of the external environment on the firm and the strategies the firms use to insure that the value of the firm is maximized 


\section{Determinants of Corporate Structure}

Determinants of corporate structure are factors that generally influence the structural composition of capital in use by an organization. As relayed in Chechet and Olayiwola (2014), Joshua, (2008), Al-Sakran, (2001), and Hovakimian, Hovakimian and Tehranian (2004) these factors includes firm size, firm age, firm asset structure, firm profitability, firm growth, taxes, non-tax debt shields, volatility and industrial classification. The size of a firm has been viewed as one of its specific characteristics that determine its corporate structure. Observably larger firms tend to use more of debt while smaller ones are more likely to use equity, in their respective finances. Asset structure of a firm plays a very critical function in determining its corporate structure, the degree to which assets of a firm are tangible should result to greater liquidation value for the firm. The firm's age means how old a business is in its operations. It is determinant of its reputation gathered from experience over the years which in turn results to goodwill. As firms operate over the years, it establishes and strengthens itself as an ongoing concern which builds its chances to take on more debts. It is therefore believed that age is positively related to capital structure of a firm. As a matter of empirical support, many previous studies have proven the relationship between a firm's age and corporate structure to be positive (Julius, Nwidobie, \& Adesina, 2015)

\section{Empirical Review}

The connection between corporate structure and performance of firms communicated through financial reporting has been analyzed via investigation of the impact of capital structure and/or ownership structure and performance of firms around the world. Some of these studies are reviewed below:

Peterson and Olayinka, (2017), examined ownership concentration and bank profitability in a developing country context. In the study ownership concentration was measured as amount of direct equity held by majority of shareholder, and also categorized into high ownership concentration, moderate ownership concentration and disperse ownership concentration. The study employed annual panel data spanning across 27 banks over a period 2006 to 2015. Using static and dynamic panel model estimation techniques, the study found that banks with high ownership concentration have higher return on assets, higher net interest margin and higher recurring earning power while banks with dispersed ownership have lower return on asset but have higher return on equity, also higher cost efficiency improves the return on asset of widely help banks and the return on equity of banks with moderate ownership, the study concluded that banks with concentrated ownership record higher profitability but their profitability do not appear to be significantly driven by economic drivers of bank profitability. A study conducted by Nguyen, Tran, Dinh, Lai and Pham, (2015) examined the impact of ownership structure and performance of Vietnamese banks. The study sourced data from 44 banks in the banking system of Vietnamese, covering a time period spanning between 2010 to 2012. Using descriptive statistical analysis, it was established in the study that capital concentration and private ownership have positive impact on bank profitability.

In Ethiopia Aragaw (2015) assessed the impact of capital structure on profitability of commercial banks employing quantitative panel data analysis, using secondary data sourced from audited financial statement of eight commercial banks and national bank of Ethiopia for the period of twelve years spanning from 2002-s2013. It was observed that $89 \%$ of the total capital of commercial banks in Ethiopia in the period under study was made up of debt. Of this, $75 \%$ constitute deposit and the remaining was non-deposit liabilities. This has reaffirmed the fact that banks are highly levered institutions. The findings revealed that capital structure as measured by total debt to asset had statistically significant negative impact, whereas deposit to asset had statistically significant positive impact on profitability of core business operations of commercial banks. Taiwo (2016), examined the optimum level of capital structure through 
which a firm can increase its financial performance using annual data of ten firms spanning a five-year period. The study made use of Pesaran \& Shine unit root test as well as panel least square. Result showed that all the variables were non-stationary at level. However, the results from Panel Least Square (PLS) confirm that asset turnover, size, firm's age and firm's asset tangibility are positively related to firm's performance. Findings provide evidence of a negative and significant relationship between asset tangibility and ROA as a measure of performance in the model.

Aremu, Ekpo, Mustapha and Adedoyin (2013), investigated into the determinants of capital structure in Nigeria banking sector for the period of four years spanning through 2006-2010. The pooled ordinary Least Square (Pooled OLS) technique was employed in obtaining the numerical estimates of the coefficients in different equations. The study found out that the main determinant factors which contribute to the bank leverage level of the Banking industry in Nigeria between the years 2006 to 2010 are mainly bank size, dividend payout, profitability, tangible assets, growth, business risk and tax charge factors with all of these factors conforming to sign expectations based on theoretical findings. It was recommended in the study that future studies should increase the length of the research period of the study to ensure that there is no biasness in drawing up samples for conclusions. Osuji, and Odita, (2012) investigated the Impact of capital structure on the financial performance of Nigerian firms. The study used a sample of thirty non-financial firms listed on the Nigeria stock exchange for a period of seven years spanning from 2004-2010. Panel data for the selected firms were generated and analyzed using ordinary least squares (OLS) as a method of estimation. the result from the analysis shows that a firm's capital structure surrogated by debit ratio, and it has a significant negative impact on the firm's financial measures (return on asset (ROA), and return on equity (ROE)). The study concluded based on the findings, that the firm's capital structure is an important determinant of firms financial performance and the direction of the relationship is reverse. The outcome provides evidence in support of the agency cost hypothesis. It further reveals that asset turnover, is an important determinant of financial performance.

Khalaf, (2013) explained Capital structure effects on banking performance: a case study of Jordan. The annual financial statements of 12 commercial banks listed on Amman stock exchange were used for this study which covers a period of 5 years from 2007-2011. Multiple regression was applied on performance indicators such as net profit (NP). Return on capital employed (ROCE). Return on equity (ROE) and net interest margin (NIM) as well as total debt to total funds (TDTF) and total debt to total equity (TDTE) as capital structure variables. The study applied multiple regression models to estimate the relationship between capital structure and banking performance. The results show that bank performance which is measured by net profit, return on capital employed and net interest margin is to be significantly and positively associated with total debt, while total debt is found to be insignificant in determining return on equity in the banking industry of Jordan. Erasmus and James (2014) examined capital structure and firm performance. The study specifically assessed the impact of capital structure on bank performance in Tanzania. Efficiency of bank, return on assets and return on equity were considered separately as measures of bank performance. Explanatory variables were total debt to equity ratio, long term debt to equity ratio, short term debt to equity ratio, total asset to debt ratio, long term asset to debt ratio and short term asset to debt. The study collated data for 38 banks in Tanzania for the period 20072011. The data were analysed using descriptive analysis, partial correlation analysis and fixed effect model. The study revealed that banks in Tanzania use more debts as their source of finance than equity financing. Also, the study revealed negative trade-off between the use of debts and firm performance. Thus, the study recommended that commercial banks in Tanzania 
have a chance of using commercial debts to expand their services to rural areas and other areas with unbanked population.

Julius, Barine, and Oluwatosin (2015) assessed capital structure and financial performance in Nigeria. Specifically, the study explored the impact of post-consolidation capital structure on the financial performance of Nigeria quoted banks. Capital base was measured by debt and equity while bank performance was measured by profit before tax. The study sampled ten Nigerian banks quoted on the Nigerian Stock exchange from period 2005 to 2012. Data were analyzed using descriptive analysis, correlation and regression analysis. The study revealed that debt and equity have positive and significant influence on profit before tax. Therefore, the study concluded that bank debt and bank equity have positive and significant impact on bank performance. Investigation conducted by Adedoyin (2014) focused on capital structure and the value of firm. The study specifically explored the impact of capital structure decision of Nigerian banks on its value. The dependent variable was value of the firm, while the explanatory variables are debt and equity. The study collated data from 2007-2012 for 15 publicly owned commercial banks in Nigeria. The data were analyzed using ordinary least square technique and Heteroskedasticity Consistent Covariance. The result revealed that equity and debt have positive impact on the value of firm. However, the significance of equity is low while that of debt is high. Therefore, the study concluded that debt instrument is a major component that magnifies the value of firm.

\section{Model Specification}

\section{METHODOLOGY}

The study measured financial reporting in terms of profit after tax (PAT), and earnings per share (EPS) reported on the financial statement as indicators of performance. On the other hand corporate structural change was captured by change in share capital (CSC), and change in share premium (CSP) within a fiscal year (calculated as absolute difference between the end period value and start period value). The model was controlled by firms size (FZ). Function and linear presentations of the two models estimated in the study are given below:

$$
\begin{aligned}
& P A T_{i t}=\delta_{0}+\delta_{1} C S C_{i t}+\delta_{2} C S P_{i t}+\delta_{3} F Z_{i t}+\mu_{1 t}----(i) \\
& E P S_{i t}=\delta_{0}+\delta_{1} C S C_{i t}+\delta_{2} C S P_{i t}+\delta_{3} F Z_{i t}+\mu_{2 t}------(i i)
\end{aligned}
$$

Where:

PAT=Profit after tax (in million naira)

EPS=Earnings per share (in Naira)

$\mathrm{CSC}=$ change in share capital (in million naira)

$\mathrm{CSP}=$ change in share premium (in million naira)

FZ=firm size (natural log of total asset)

$\mu_{i t}$ represent the error term,

\section{Source(s) of Data and Method of Analysis}

The study focused on five money deposit banks in Nigeria, including Access Bank Plc, Diamond Banks Plc, First Bank Plc, Guaranty Trust bank Plc, and First City Monument Bank Plc. Secondary data used in the study sourced from the annual reports of the sampled banks covering a period of five years (2011 to 2015). Data collated were analyzed using correlation analysis, pooled OLS estimation, fixed effect estimation and random effect estimation, followed by post estimation test for evaluating estimations for consistency and efficiency. 


\section{Data Analysis and Interpretation Correlation Analysis}

Table 1: Correlation matrix

\begin{tabular}{|l|l|l|l|l|l|}
\hline & PAT & EPS & CSC & CSP & FZ \\
\hline PAT & 1.0000 & & & & \\
\hline EPS & 0.6505 & 1.0000 & & & \\
\hline CSC & 0.1490 & -0.2522 & 1.0000 & & \\
\hline CSP & -0.1340 & 0.0018 & 0.3725 & 1.0000 & \\
\hline FZ & 0.3408 & 0.6888 & 0.1490 & 0.2949 & 1.0000 \\
\hline
\end{tabular}

SOURCE: Authors' Computation, (2018)

Correlation result presented in table 1 showed that profit after tax moves in the same direction with earning per share, with considerably high magnitude of 0.6505 . Profit after tax (PAT) moves in the same direction with change in share capital (CSC) given correlation coefficient of 0.1490. Correlation between profit after tax (PAT) and change in share premium (CSP) is negative and weak with reported statistics of -0.1340 , while profit after tax and firms size has mildly weak positive correlation, with reported statistics of 0.3408 . As reported in table 1 correlation is negative and weak (-0.2522) for earning per share and change in share capital, positive and weak for earning per share change in premium per share (0.0018), positive and strong for earning per share and firms size (0.6888), positive and weak for change in share capital and change in share premium (0.3725), positive and weak for change in share capital and firm's size (0.1490), positive and weak for change in share premium and firm's size (0.2949).

Table 2: Pooled OLS Estimations

\begin{tabular}{|c|c|c|c|c|}
\hline & \multicolumn{2}{|c|}{ PAT } & \multicolumn{2}{|c|}{ EPS } \\
\hline Variables & Coefficients & Probability & Coefficients & Probability \\
\hline $\mathrm{C}$ & -153633.8 & 0.101 & -8.867667 & 0.000 \\
\hline CSC & 5.729072 & 0.320 & -.0002713 & 0.036 \\
\hline CSP & -.5492376 & 0.137 & $-5.17 e-06$ & 0.508 \\
\hline $\mathrm{FZ}$ & 13029.27 & 0.057 & .7521933 & 0.000 \\
\hline & \multicolumn{2}{|c|}{$\begin{array}{l}\text { R-square }=0.4152 \\
\text { Adjusted R-square= } 0.4031 \\
\text { F-stat= } 11.92 \\
\text { Prob(F-stat) }=0.0074\end{array}$} & \multicolumn{2}{|c|}{$\begin{array}{l}\text { R-square }=0.6115 \\
\text { Adjusted R-square }=0.5560 \\
\text { F-stat }=11.02 \\
\text { Prob(F-stat) }=0.0001\end{array}$} \\
\hline
\end{tabular}

Source: Author's Computation, (2017)

Pooled OLS estimation result presented in table 2 revealed that changes in share capital exerts insignificant positive impact on profit after tax, with coefficient estimates of $5.729072(\mathrm{p}=0.320$ $>0.05)$, while the impact of changes in share premium on profit after tax is negative and insignificant with coefficient estimate of $-0.5492376(\mathrm{p}=0.137>0.05)$. Reported R-square statistics for the estimation showing the impact of structural changes on profit after tax when heterogeneity effect across firms is not given consideration stood at 0.4152 , which reflect that changes in corporate structure measured in terms of changes in share capital and share premium within the fiscal year alongside control variable-firm's size can only explain about $42 \%$ of the systematic variations in profit after tax or sampled firms. On the other hand result of the model showing the impact of structural changes on earnings per share when firm's uniqueness is not incorporated, revealed that changes in share capital exerts significant negative impact on earnings per share, with coefficient estimate of $-0.0002713(\mathrm{p}=0.036<$ 0.05), while changes in share premium exerts insignificant negative impact on earnings per share with coefficient estimate of $-5.17 e-06(p=0.508>0.05)$. R-square value reported for the 
estimation reflect that changes in share capital, changes in share premium, and firm's size can explain about $61 \%$ of the systematic variation in earnings per share of sampled firms when heterogeneity effect is not given consideration. For more robust investigation into the subject matter of corporate structural changes and financial reporting of banks in the country, heterogeneity effect was incorporated into the models using fixed effect and random effect approaches. Result of estimations conducted using the two approaches are presented in tables below:

Table 3: Fixed effect Estimations

\begin{tabular}{|c|c|c|c|c|}
\hline & \multicolumn{2}{|c|}{ PAT } & \multicolumn{2}{|c|}{ EPS } \\
\hline Variables & Coefficients & Probability & Coefficients & Probability \\
\hline $\mathrm{C}$ & -90308.2 & 0.277 & -4.651146 & 0.049 \\
\hline $\mathrm{CSC}$ & 1.780255 & 0.586 & -.0002728 & 0.006 \\
\hline CSP & .1894487 & 0.355 & $2.75 \mathrm{e}-06$ & 0.619 \\
\hline $\mathrm{FZ}$ & 8730.395 & 0.142 & .4225384 & 0.014 \\
\hline \multicolumn{5}{|l|}{ Fixed Effect } \\
\hline Diamond Bank & -16944.12 & 0.120 & .072868 & 0.799 \\
\hline First Bank & -44896.74 & 0.002 & .2966759 & 0.375 \\
\hline GTBank & 45610.12 & 0.000 & 1.475728 & 0.000 \\
\hline \multirow[t]{2}{*}{ FCMB Bank } & -15186.88 & 0.288 & -.3363412 & 0.385 \\
\hline & \multicolumn{2}{|c|}{$\begin{array}{l}\text { R-square }=0.8566 \\
\text { Adjusted R-square }=0.7976 \\
\text { F-stat }=14.51 \\
\text { Prob(F-stat) }=0.0000\end{array}$} & \multicolumn{2}{|c|}{$\begin{array}{l}\text { R-square }=0.8867 \\
\text { Adjusted R-square }=0.8401 \\
\text { F-stat }=19.01 \\
\text { Prob(F-stat) }=0.0000\end{array}$} \\
\hline
\end{tabular}

Source: Author's Computation, (2017)

Table 3 reported estimation result showing the impact of corporate structural changes on profit after tax earnings per share, when heterogeneity effect across banks sampled in the study is incorporated as into the intercept terms for each sampled banks. Result showed that when both changes in share capital, and changes in share premium exerts insignificant positive impact on profit after tax with coefficient estimates of $1.780255(\mathrm{p}=0.586>0.05)$ and $0.1894487(\mathrm{p}=0.355>0.05)$ respectively. reported intercept deviation terms stood at $16944.12(\mathrm{p}=0.120>0.05),-44896.74(\mathrm{p}=0.002<0.05), 45610.12(\mathrm{p}=0.000<0.05), \quad-$ 15186.88( $\mathrm{p}=0.288>0.05)$ for Diamond Banks Plc, First Bank Plc, Guaranty Trust Bank Plc, and First City Monument Bank Plc respectively, with Access Bank Plc as the reference firm. The result also revealed that about $86 \%$ of the systematic variation in profit after tax can be explained by corporate structural changes measured in terms of change in share capitals, and changes in share premium, when the model is controlled for firm's size. On the other hand result presented in table 3 showed that when heterogeneity effect across banks sampled in the study is incorporated into the model, changes in share capital exerts significant negative impact on earnings per share, with coefficient estimate of $-.0002728(\mathrm{p}=0.006<0.05)$, while impact of changes in share premium on earnings per share is positive but not significant 2.75e$06(\mathrm{p}=0.619>0.05)$. Deviation intercept terms reported for the estimation stood at $.072868(\mathrm{p}=0.799>0.05)$, for Diamond Bank Plc, $0.2966759(\mathrm{p}=0.375>0.05)$ for First Bank Plc, 1.475728( $\mathrm{p}=0.375>0.05)$ for Guaranty Trust Bank, and -.3363412( $\mathrm{p}=0.385>0.05)$ for First City Monument Bank, while report R-square stood at 89\%. 
Table 4: Random Effect Estimation

\begin{tabular}{|c|c|c|c|c|}
\hline & \multicolumn{2}{|c|}{ PAT } & \multicolumn{2}{|c|}{ EPS } \\
\hline Variables & Coefficients & Probability & Coefficients & Probability \\
\hline $\mathrm{C}$ & -153633.8 & 0.086 & -7.349286 & 0.000 \\
\hline $\mathrm{CSC}$ & 5.729072 & 0.308 & -.0002863 & 0.006 \\
\hline CSP & -.5492376 & 0.122 & $-1.61 e-07$ & 0.980 \\
\hline \multirow[t]{2}{*}{$\mathrm{FZ}$} & 13029.27 & 0.044 & .6403575 & 0.000 \\
\hline & \multicolumn{2}{|c|}{$\begin{array}{l}\text { R-square }=0.5952 \\
\text { Wald chi } 2=15.76 \\
\text { Prob }(\text { chi2 })=0.0040\end{array}$} & \multicolumn{2}{|c|}{$\begin{array}{l}\text { R-square }=0.6028 \\
\text { Wald chi2 }=25.27 \\
\text { Prob }(\text { chi } 2)=0.0000\end{array}$} \\
\hline
\end{tabular}

Source: Author's Computation, (2017)

Random effect estimation result presented in table 4 revealed that when heterogeneity effect across sampled banks is incorporated into the random term, changes in share capital exerts insignificant positive impact on profit after tax, with coefficient estimate of $5.729072(\mathrm{p}=0.308$ $>0.05)$, while impact of changes in share premium is negative and insignificant $0.5492376(p=0.122>0.05)$, on the other hand both changes in share capital and share premium exerts negative impact on earnings per share, while impact of change in share capital is significant with coefficient estimate of $-.0002863(\mathrm{p}=0.006<0.05)$, that of change in share premium is not significant $-1.61 \mathrm{e}-07(\mathrm{p}=0.980>0.05)$. Reported R-square stood at about $60 \%$ for model 1 and model 2 . Thus showing that about $60 \%$ of the systematic variation in the profit after tax as well as earnings per share can be explained by changes in share capital and changes in share premium when heterogeneity effect across firms is incorporated into the random term.

\section{Post Estimation Test:}

Table 5: Restricted F Test of Heterogeneity

\begin{tabular}{|l|c|c|}
\hline & F-statistics & Probability \\
\hline Model 1 & 19.02 & 0.0000 \\
\hline Model 2 & 10.33 & 0.0002 \\
\hline
\end{tabular}

Source: Author's Computation, (2016)

Table 6: Hausman Test

\begin{tabular}{|l|c|c|}
\hline & Chi-square stat & Probability \\
\hline Model 1 & 4.10 & 0.0640 \\
\hline Model 2 & 4.13 & 0.2481 \\
\hline
\end{tabular}

Source: Author's Computation, (2016)

Given the result of post estimation tests conducted in the study for evaluation of the estimator used (Pooled OLS, Fixed effect estimation, and random effect estimation) as presented in tables 5 and table 6 , it become obvious that the most consistent and efficient estimation results for the investigation conducted in the study are the random effect estimations presented in table 4 above. Hence analysis and inference in this study was based on the findings reflected on the random effect estimation results.

\section{DISCUSSION}

Result presented in table 4 reflect that corporate structural changes measured in terms of changes in share capital has insignificant positive impact of profit after tax reported by firms on the statement of account as performance indicator, with a million naira increase in changes in share capital resulting into only about 5.7 million naira increase in profit after tax, given the reported coefficient estimate corresponding to change in share capital that stood at 5.729072 
alongside probability value of 0.308 . Corporate structural changes measured in terms changes in share premium exert insignificant negative impact on profit after tax of banks sampled in the study, with every million increase in change in share capital within a fiscal year resulting into less than one million decline in profit after, given the reported coefficient estimate of .5492376 alongside probability values of 0.122 . Result also showed that corporate structural changes measured in terms of change in share capital exert significant negative impact on earnings per share, as a million naira increase in change in share capital culminates into about 0.0002863 naira decline in earnings per share in the same year. Corporate structural changes measured in terms of change in share premium exert insignificant impact on earnings per share of banks sampled in the study, with a million naira increase in share premium exerting an infinitesimal decline in earnings per share.

\section{CONCLUSION AND RECOMMENDATION}

Premise on the discoveries made in the study, it can be established that corporate structural changes has traceable influence on financial reporting of firms in Nigerian banking industry, with measures of structural changes influencing the position of financial facts communicated through financial reporting as performance indicators. In a nutshell the study made it clear that any changes in the structural composition of finance mix in terms share capital and share premium exert measurable influence of indicators such as profit after tax and earnings per share reported by firms for awareness of the operational outcome for the years to stakeholders including government, regulatory authorities as well as standpoint for investment by prospective investors. Thus firms in the banking industry should objectively design corporate structural framework that can withstand flexibility and dynamics of business operation in the industry, so as to guide against excessive inconsistencies in financial reporting as a result of structural changes.

\section{References}

Abdabi, S \& Abu-Rub, N (2012), The effect of Capital Structure on the Performance of Palestian Financial Institutions, British Journal of Economics, Finance and Management Sciences, 3(2), 92-101.

Adedoyin, I.L. (2014). Capital structure and the value of firm: evidence from the Nigeria banking industry. Journal of Accounting and Management, 4(1), 31-41

Aftab M, Ehsan R, Naseer S, Awan T (2012). The effect of corporate strategy and capital structure on performance of banking sector of Pakistan. Global Journal of Management and Business Research 12(17), 67-79

Aremu, M.A, Ekpo, I.C, Mustapha, A.M and Adedoyin, S.I (2013),. Determinants of capital structure in Nigeria banking sector. International Journal of Academic Research in Economics and Management Sciences. 2(4), 29-43.

Chechet, I \& Olayiwola (2014), Capital Structure and Profitability of Nigeria Quoted Firms. The Agency Cost Theory Perspective, American International Journal of Social Science, 3(1), 139-158.

Erasmus, F.K. and James, J.M. (2014). Capital structure and firm performance: evidence from commercial banks in Tanzania. Research Journal of Finance and Accounting, 5(14), 168-179

Hovakimian, A., G. Hovakimian and H. Tehranian (2004). Determinants of target capital structure: the case of dual debt and equity issues. Journal of Financial Economics, 7(1), 517-540

Julius, B.A, Nwidobie, B.M, \& Adesina, 0.0 (2015), capital structure and financial performance in Nigeria international journal of business and social research 5(2) 1-15

Julius, B.A., Barine, M.N. and Oluwatosin, O.A. (2015). Capital structure and financial performance in Nigeria. International Journal of Business and Social Research, 5(2), 21-31

Khalaf .T (2013). Capital structure effects on banking performance: A case study of Jordan. International Journal of economics, finance and management sciences. 1(5), 227-233

Khalaf, T, (2013). Capital structure effects on banking performance: a case study of Jordan. International Journal of Economics, Finance and Management Science. 1(5), 227-233.

Lawal A.I (2014) Capital structure and the value of the firm: Evidence from the Nigeria banking industry. Journal of accounting and management Jam 4(1), 23-44 
Lawrence, I. (2015). Capital base and performance of money deposit banks in Nigeria: pre and post consolidation Era. International Journal of Managerial Studies and Research, 3(1), 74-82

Muhammad, A.S (2011),. Measuring performance through capital structure: evidence from banking sector of Pakistan. African Journal of Business Management. 5(5), 1871-1879.

Muhammad. A, Rehan. E, and Saad. N, (2012). The effect of corporate strategy and capital performance of banking sector of Pakistan. Global journal of management and business. 12(17), 2249-4588.

Oke 0.0 and Afolabi B (2011), capital structure and industrial performance in Nigeria (1999-2007). International Business and Management 2(1) 100-106

Osuji, C.C, Odita, A, (2012). Impact of capital sstructure on the financial performance of Nigerian firms. Arabian journal of business and management review. 1(12), 43-61.

Peterson kitakogelu. O, Olayinka. U, (2017). Ownership concentration and bank profitability. Future business journal, 3(2017), 159-171

San, O. T. and Heng, T. B. (2011), "Capital structure and corporate performance of Malaysian construction sector". International Journal of Humanities and Social Science, 1(2), 28 - 36.

Siddiqui, M., \& Shoaib, A. (2011). Measuring performance through capital structure: Evidence from banking sector of Pakistan. African Journal of Business Management, 5(5), 1871-1879.

Suleiman M.A and Nour, A.R (2012),. The effect of capital structure on the performance of palestinian financial institutions. British journal of economics, finance and management sciences. 3(2), 92-101.

Taiwo, A.M (2016). An empirical analysis of capital structure on firms' performance in Nigeria. International Journal of Advances in Management and Economics, 27(1), 116-124.

Velnampy. T, Aloy, J.N, (2012). The relationship between capital structure and profitability. Global journal of management and business, 12(13), 2249-4588. 